\title{
Asupan makan, status gizi, dan kualitas hidup pasien kanker payudara di RSUP Dr Sardjito Yogyakarta
}

Nutrition intake, nutritional status and quality of life breast cancer patients in Sardjito Hospital Yogyakarta

\section{Susetyowati $^{1}$, Retno Pangastuti ${ }^{2}$, Sri Retna Dwidanarti ${ }^{2}$, Hanifah Wulandari ${ }^{1}$}

${ }^{1}$ Departemen Gizi Kesehatan, Fakultas Kedokteran, Kesehatan Masyarakat, dan Keperawatan Universitas Gadjah Mada

${ }^{2}$ Rumah Sakit Umum Pusat Dr. Sardjito Yogyakarta

\begin{abstract}
Background: Breast cancer is the fifth leading cause of death due to all the type of cancer and the second leading cause of death in developing country after lung cancer. The global incidents of this disease were $43 \%$. The cancer cells have an ability to disturb the nutrients absorbtion in the body and give an effect of decreasing nutritional status, physical performance and quality of life. Objective: To show the relationship between nutrient intake, nutritional status and quality of life, breast cancer patients with radiotherapy at Sardjito Hospital Yogyakarta. Method: This study was an observational study with cross sectional design. Total subject of this study were 85 respondents. Intake of energy, protein, fat and carbohydrate were measured using $1 \times 24$ hours food recall. Nutritional status were measured using patient-generated subjective global assessment (PG-SGA) questionnaire. Then the quality of life were measured using European Organization for Research and Treatment of Cancer Quality of Life Questionnaire (EORTC QLQ-C30) questionnaire. Results: There were significant difference in the average intake of energy ( $p=0.013)$, protein $(p=0.043)$ and fat $(p=0.016)$ between severe malnourished, moderate malnourished and wellnourished patients, whereas the average intake of carbohydrate was not significant $(p=0.070)$. The lower nutrition intake, the lower nutritional status. There was also significant difference in fat intake $(p=0.035)$ and nutritional status based on PG-SGA $(p=0.002)$ between patients with poor and good quality of life. Patients with poor quality of life had lower nutrition intake and nutritional status. Conclusion: Nutrient intake gave an effect to nutritional status and quality of life in breast cancer patient with radiotherapy.
\end{abstract}

KEY WORDS: breast cancer; nutrient intake; nutritional status; quality of life

\begin{abstract}
ABSTRAK
Latar belakang: Kanker payudara merupakan penyebab kematian nomor lima di antara semua jenis kanker dan nomor kedua penyebab kematian akibat kanker di negara berkembang setelah kanker paru. Tingkat insidensi kanker payudara secara global sebesar 43,3\%. Sel kanker dapat mengganggu penyerapan zat gizi sehingga mempengaruhi penurunan status gizi dan berdampak pada performa fisik serta kualitas hidup. Tujuan: Penelitian ini bertujuan untuk mengetahui hubungan antara asupan makan, status gizi, dan kualitas hidup pasien kanker payudara dengan radioterapi di RSUP Dr. Sardjito Yogyakarta. Metode: Penelitian observasional dengan desain cross sectional dan jumlah subjek penelitian sebesar 85 responden. Asupan energi, protein, lemak, dan karbohidrat diukur menggunakan food recall 1x24 jam. Status gizi diukur menggunakan kuesioner Patient-Generated Subjective Global Assessment (PG-SGA). Kualitas hidup diukur menggunakan kuesioner European Organization for Research and Treatment of Cancer (EORTC QLQ-C30). Hasil: Terdapat perbedaan yang signifikan rerata asupan energi $(\mathrm{p}=0,013) ; \mathrm{protein}(\mathrm{p}=0,043)$; dan lemak $(p=0,016)$ antara pasien yang tergolong malnutrisi berat, sedang, dan status gizi baik, sedangkan asupan karbohidrat tidak berbeda secara signifikan $(\mathrm{p}=0,070)$. Semakin rendah asupan makan, semakin berat kondisi malnutrisinya. Terdapat perbedaan yang signifikan pula pada asupan lemak $(\mathrm{p}=0,035)$ dan status gizi berdasarkan PG-SGA $(\mathrm{p}=0,002)$ antara pasien dengan kualitas hidup yang kurang dan baik. Pasien dengan kualitas hidup yang kurang memiliki asupan makan dan status gizi yang lebih rendah. Simpulan: Asupan makan mempengaruhi status gizi dan kualitas hidup pada pasien kanker payudara yang menjalani radioterapi.
\end{abstract}

KATA KUNCI: kanker payudara; asupan makan; status gizi; kualitas hidup

Korespondensi: Susetyowati, Departemen Gizi Kesehatan, Fakultas Kedokteran, Kesehatan Masyarakat, dan Keperawatan Universitas Gadjah Mada, J1. Farmako, Sekip Utara Yogyakarta 55281, e-mail: susetyowati@ugm.ac.id 


\section{PENDAHULUAN}

Kanker payudara (Carcinoma mammae) merupakan kondisi adanya tumor ganas yang menyerang jaringan payudara seperti kelenjar susu (kelenjar pembuat air susu), saluran kelenjar (saluran air susu), dan jaringan penunjang payudara (1). Kanker payudara merupakan penyebab kematian nomor lima di antara semua jenis kanker dan nomor kedua penyebab kematian akibat kanker di negara berkembang setelah kanker paru (2). Data global menunjukkan bahwa tingkat insidensi kanker payudara sebesar 43,3\% (3). Di Indonesia, prevalensi penyakit kanker mencapai 1,4\% atau sekitar 347.792 orang. Daerah Istimewa Yogyakarta (DIY) merupakan daerah yang memiliki prevalensi kanker payudara tertinggi yaitu sebesar 2,4\% (4).

Kanker dapat menyebabkan efek merugikan bagi status gizi sehingga penderitanya dapat mengalami malnutrisi atau kaheksia. Tanda dari terjadinya kaheksia yaitu tubuh kurus kering dan lemah lunglai seperti orang kelaparan. Malnutrisi pada pasien kanker dapat disebabkan oleh faktor primer (umur, pengetahuan gizi, asupan makanan, infeksi) dan faktor sekunder (stadium kanker, terapi pengobatan) (5). Penurunan asupan makan pada pasien kanker dapat disebabkan oleh beberapa faktor seperti penurunan nafsu makan, depresi, munculnya gejalagejala seperti mukositis, perubahan pengecapan, mual dan muntah, diare, kelelahan, nyeri, dan kesulitan menelan (6). Terapi kanker seperti radioterapi, kemoterapi, imunoterapi, pembedahan ataupun kombinasi, juga dapat memunculkan efek samping yang terjadi pada saluran pencernaan dan mengakibatkan terganggunya asupan makan (7).

Penurunan asupan makan berdampak pada menurunnya status gizi (8). Sebuah penelitian mengidentifikasi $28,3 \%$ pasien radioterapi tergolong malnutrisi sedang dan 6,7\% malnutrisi berat (9). Malnutrisi perlu dicegah dan diatasi sedini mungkin karena dapat menyebabkan penurunan kualitas hidup dan performa fisik (10). Pasien yang memiliki status gizi baik juga cenderung memiliki harapan hidup yang lebih lama (11). Pengukuran status gizi seseorang dapat dilakukan dalam beberapa metode, diantaranya adalah pengukuran indeks masa tubuh (IMT) dan lingkar lengan atas (LILA), persen lemak tubuh, dan kekuatan genggam tangan (handgrip strength). Sebuah metode pengukuran lainnya yang dapat digunakan adalah Patient-Generated Subjective Global Assessment (PG-SGA) yang merupakan pengembangan dari Subjective Global Assessment (SGA) yang telah divalidasi untuk pasien kanker dan telah menjadi instrumen yang direkomendasikan oleh American Dietetic Association (12).

Pengukuran kualitas hidup bagi pasien kanker juga sangat diperlukan untuk melihat sejauh mana penyakit dan pengobatan yang dilakukan mempengaruhi kehidupan pasien, baik dari aspek fisik, psikologis, sosial, dan spiritual (13). Salah satu metode yang valid, reliabel, dan spesifik untuk mengukur kualitas hidup pasien kanker adalah dengan menggunakan European Organization for Research and Treatment of Cancer Quality of Life Questionnaire (EORTC QLQ-C30) (9).

Lebih lanjut, Rumah Sakit Umum Pusat (RSUP) Dr. Sardjito merupakan rumah sakit dengan jumlah kasus kanker cukup tinggi di Yogyakarta yaitu 1.033 orang pada tahun 2009 dan meningkat menjadi 1.420 orang pada tahun 2013. Berdasarkan jumlah total pasien di tahun 2013 , hanya 856 orang diantaranya yang menjalani pengobatan radioterapi. Oleh karena itu, RSUP Dr. Sardjito dipilih oleh peneliti sebagai lokasi penelitian terkait malnutrisi dan kualitas hidup. Tujuan penelitian ini adalah mengetahui hubungan antara asupan makan, status gizi, dan kualitas hidup pasien kanker payudara dengan radioterapi di RSUP Dr. Sardjito Yogyakarta.

\section{BAHAN DAN METODE}

Jenis penelitian ini adalah observasional dengan desain penelitian cross sectional. Penelitian dilakukan di Instalasi Radioterapi, Unit Radiologi RSUP Dr. Sardjito Yogyakarta pada bulan Agustus sampai dengan Desember 2016. Subjek penelitian adalah pasien yang memenuhi kriteria inklusi dan eksklusi yang ditetapkan. Kriteria inklusinya yaitu pasien dewasa yang terdiagnosis kanker payudara tanpa metastasis, sedang menjalani radioterapi di RSUP Dr. Sardjito, bersedia ikut dalam penelitian dengan menandatangani informed consent, memiliki kesadaran baik (compos mentis) serta mampu berkomunikasi dengan baik. Sementara kriteria eksklusi adalah pasien yang tidak dapat diukur tinggi dan berat badannya. Sampel diambil dengan metode purposive sampling sehingga diperoleh 85 pasien. 
Variabel dalam penelitian ini adalah asupan, status gizi, dan kualitas hidup. Asupan energi, protein, lemak, dan karbohidrat diukur menggunakan kuesioner food recall 1x24 jam. Asupan energi tergolong cukup apabila memenuhi minimal 80\% kebutuhan pasien kanker sebesar $32 \mathrm{kkal} / \mathrm{kg}$ berat badan ideal (BBI), protein $1 \mathrm{~g} / \mathrm{BB}$, lemak $25 \%$ dari total kebutuhan energi, dan karbohidrat dihitung by difference (14). Asupan zat gizi dihitung dengan software nutrisurvey.

Status gizi yang diukur meliputi indeks massa tubuh (IMT), lingkar lengan atas (LILA), persen lemak tubuh, kekuatan genggam tangan, kadar hemoglobin serta kuesioner PG-SGA. IMT diperoleh dari hasil pengukuran tinggi badan menggunakan mikrotoa dalam satuan $\mathrm{cm}$ dan berat badan menggunakan timbangan berat badan dalam satuan $\mathrm{kg}$. LILA diukur dengan menggunakan metline dalam satuan $\mathrm{cm}$ pada titik tengah antara akromion dan olekranon. Persen lemak tubuh diukur dengan menggunakan bioelectrical impedance analysis (BIA) dalam satuan persen $(15,16)$. Kekuatan genggam tangan diukur menggunakan hand dynamometer, pasien diminta menarik handgrip sekuat mungkin menggunakan tangan kanan dan nilai yang muncul dicatat dalam satuan kg (17). Pengukuran kadar hemoglobin ( $\mathrm{Hb})$ dilakukan di Instalasi Laboratorium Klinik RSUP Dr. Sardjito menggunakan metode spektrofotometri dengan kadar normal $12-15 \mathrm{mg} / \mathrm{dl}$.

Kuesioner PG-SGA membagi kategori malnutrisi berdasarkan beberapa kriteria, diantaranya riwayat penurunan berat badan, asupan zat gizi, gejala yang berkaitan dengan zat gizi, fungsional, dan pemeriksaan fisik. Skor PG-SGA 0-3 menunjukkan kategori PG-SGA A (gizi baik), skor PG-SGA 4-8 menunjukkan kategori PG-SGA B (malnutrisi sedang), dan skor PG-SGA lebih dari atau sama dengan 9 menunjukkan kategori PG-SGA C (malnutrisi berat) (18). Kuesioner EORTC QLQ-C30 yang telah diuji validitas dan reliabilitas di Indonesia terdiri dari 30 item pertanyaan yang mewakili skala fungsional (fungsi fisik, peran, emosional, kognitif, dan sosial), skala gejala (kelelahan, mual muntah, nyeri, sesak napas, insomnia, hilang nafsu makan, konstipasi, diare, dan kesulitan finansial) serta skala kehidupan global yang kemudian menginterpretasikan kualitas hidup (13). Skor kurang dari 500 menunjukkan kualitas hidup buruk sedangkan skor lebih dari atau sama dengan 500 menunjukkan kualitas hidup baik (19).

Analisis deskriptif frekuensi dilakukan untuk mengetahui karakteristik dasar responden, prevalensi malnutrisi, dan kualitas hidup. Uji One-Way Annova digunakan untuk mengetahui perbedaan rerata asupan makan dan status gizi pada kelompok PG-SGA A, B, dan C. Perbedaan rerata asupan makan dan status gizi pada kelompok kualitas hidup kurang dan baik diketahui menggunakan uji statistik independent sample t-test apabila data terdistribusi normal dan Mann-Whitney $U$ test apabila data tidak terdistribusi normal. Penelitian ini telah mendapatkan izin dari Komisi Etik Fakultas Kedokteran Universitas Gadjah Mada dengan nomor KE/FK/921/EC/2016.

\section{HASIL}

\section{Karakteristik subjek penelitian}

Berdasarkan hasil penelitian dapat diketahui bahwa di antara 85 responden, sebagian besar berusia di atas 50 tahun (56,5\%), berpendidikan terakhir SMA $(34,1 \%)$, tidak bekerja atau menjadi ibu rumah tangga (70,6\%), dan $25,9 \%$ responden memiliki penyakit kanker pada stadium awal (0, I, II). Radioterapi dilaksanakan selama 25-30 kali dengan frekuensi 5 kali per minggu (20). Sebagian besar responden sedang menjalani terapi pada minggu kedua $(34,1 \%)$. Selain itu, hampir seluruh responden sudah menjalani tindakan operasi dan kemoterapi serta tidak memiliki penyakit yang menyertai kanker (Tabel 1).

\section{Gambaran asupan makan, status gizi, dan kualitas hidup}

Sebagian besar asupan energi, protein, dan lemak responden pada saat radioterapi masih tergolong kurang dari kebutuhan. Sementara itu, sebagian besar asupan karbohidrat responden telah mencukupi kebutuhan. Gambaran asupan makan responden dapat dilihat pada Gambar 1.

Hasil penilaian status gizi menunjukkan bahwa sebagian besar subjek memiliki status gizi baik hingga obesitas. Berdasarkan IMT, sebanyak 30,6\% responden tergolong gizi baik dan 29,4\% tergolong obesitas. Berdasarkan persen lemak tubuh, 11,8\% responden tergolong obesitas. Standar LILA untuk perempuan 
Tabel 1. Distribusi frekuensi karakteristik subjek penelitian

\begin{tabular}{|c|c|c|}
\hline \multirow{2}{*}{ Variabel } & \multicolumn{2}{|c|}{ Jumlah } \\
\hline & n & $\%$ \\
\hline \multicolumn{3}{|l|}{ Kelompok usia } \\
\hline Dewasa (30-50 tahun) & 37 & 43,5 \\
\hline Dewasa tua ( $>50$ tahun) & 48 & 56,5 \\
\hline \multicolumn{3}{|l|}{ Pendidikan } \\
\hline SD & 23 & 27,1 \\
\hline SMP & 5 & 5,9 \\
\hline SMA & 29 & 34,1 \\
\hline Sarjana dan pasca sarjana & 17 & 21,2 \\
\hline Lainnya & 10 & 11,8 \\
\hline \multicolumn{3}{|l|}{ Pekerjaan } \\
\hline Karyawan swasta & 2 & 2,4 \\
\hline Wiraswasta & 5 & 5,9 \\
\hline PNS & 10 & 11,8 \\
\hline Pensiunan & 4 & 4,7 \\
\hline Pedagang & 4 & 4,7 \\
\hline Ibu rumah tangga & 60 & 70,6 \\
\hline \multicolumn{3}{|l|}{ Stadium kanker } \\
\hline Awal $(0$, I, II) & 22 & 25,9 \\
\hline Lokal (IIIa, IIIb, IV) & 20 & 23,5 \\
\hline Lokal lanjut (IIIa, IIIb, IV) & 8 & 9,4 \\
\hline Tidak disebutkan & 35 & 41,2 \\
\hline \multicolumn{3}{|l|}{ Fraksinasi terapi } \\
\hline Minggu 1 & 11 & 12,9 \\
\hline Minggu 2 & 29 & 34,1 \\
\hline Minggu 3 & 10 & 11,8 \\
\hline Minggu 4 & 9 & 10,6 \\
\hline Minggu 5 & 26 & 30,6 \\
\hline \multicolumn{3}{|l|}{ Tindakan operasi } \\
\hline Ya & 80 & 94,1 \\
\hline Tidak & 5 & 5,9 \\
\hline \multicolumn{3}{|l|}{ Tindakan kemoterapi } \\
\hline Ya & 84 & 98,8 \\
\hline Tidak & 1 & 1,2 \\
\hline \multicolumn{3}{|l|}{ Penyakit penyerta } \\
\hline Tidak ada & 75 & 88,2 \\
\hline Asma & 1 & 1,2 \\
\hline Anemia & 1 & 1,2 \\
\hline Diabetes mellitus & 3 & 3,5 \\
\hline Maag & 1 & 1,2 \\
\hline Hipertensi & 2 & 2,4 \\
\hline Wasir & 1 & 1,2 \\
\hline Stroke & 1 & 1,2 \\
\hline
\end{tabular}

dewasa berdasarkan Application of Clinical Nutrition adalah $28,5 \mathrm{~cm}$ (21). Lingkar lengan atas responden tergolong dalam kategori baik apabila memenuhi minimal $90 \%$ standar sehingga jumlah responden dengan LILA tergolong baik sebesar 75,3\%. Kekuatan genggam tangan menunjukkan 78,8\% responden tergolong baik. Kadar

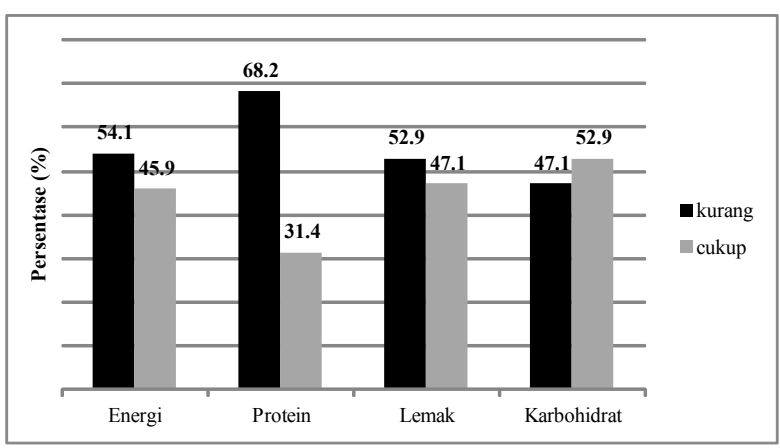

Gambar 1. Asupan makan responden

Tabel 2. Status gizi dan kualitas hidup

\begin{tabular}{|c|c|c|}
\hline \multirow{2}{*}{ Indikator } & \multicolumn{2}{|c|}{ Jumlah } \\
\hline & $\mathbf{n}$ & $\%$ \\
\hline \multicolumn{3}{|l|}{ IMT $^{1}$} \\
\hline Gizi kurang & 5 & 5,9 \\
\hline Gizi baik & 26 & 30,6 \\
\hline Gizi lebih & 29 & 34,1 \\
\hline Obesitas & 25 & 29,4 \\
\hline \multicolumn{3}{|l|}{ LILA $^{2}$} \\
\hline Kurang & 21 & 24,7 \\
\hline Baik & 64 & 75,3 \\
\hline \multicolumn{3}{|l|}{ Persen lemak tubuh } \\
\hline Underfat & 8 & 9,4 \\
\hline Normal & 36 & 42,4 \\
\hline Overweight & 31 & 36,5 \\
\hline Obesitas & 10 & 11,8 \\
\hline \multicolumn{3}{|c|}{ Kekuatan genggam tangan } \\
\hline Kurang & 18 & 21,2 \\
\hline Baik & 67 & 78,8 \\
\hline \multicolumn{3}{|l|}{ Hemoglobin (mg/dL) } \\
\hline Rendah & 20 & 30,8 \\
\hline Normal & 45 & 69,2 \\
\hline \multicolumn{3}{|l|}{ PG-SGA ${ }^{3}$} \\
\hline PG-SGA A & 50 & 58,8 \\
\hline PG-SGA B & 27 & 31,8 \\
\hline PG-SGA C & 8 & 9,4 \\
\hline \multicolumn{3}{|l|}{ Kualitas hidup } \\
\hline Kurang & 47 & 55,3 \\
\hline Baik & 38 & 44,7 \\
\hline
\end{tabular}

${ }^{1}$ IMT=Indeks Massa Tubuh; ${ }^{2}$ LILA=Lingkar Lengan Atas; ${ }^{3}$ PG-SGA=Patient Generated-Subjective Global Assessment

Hb yang normal juga ditemukan pada $69,2 \%$ responden. Berdasarkan kuesioner PG-SGA, sebesar 58,8\% responden tergolong gizi baik (PG-SGA A). Penilaian kualitas hidup menunjukkan $44,7 \%$ responden tergolong dalam kategori baik. Gambaran status gizi dan kualitas hidup responden dapat dilihat dalam Tabel 2. 
Perbandingan rerata asupan makan dan indeks status gizi pada kelompok status gizi kurang dan baik berdasarkan PG-SGA

Rerata asupan energi, protein, lemak, dan karbohidrat pada pasien dengan status gizi yang tergolong malnutrisi berat (PG-SGA C) lebih rendah dibandingkan pasien yang tergolong malnutrisi sedang (PG-SGAB) dan gizi baik (PG-SGAA). Semakin berat kondisi malnutrisi, semakin rendah juga asupan makannya. Secara statistik ada perbedaan yang signifikan rerata asupan energi, protein, dan lemak antara pasien kanker yang tergolong malnutrisi berat, sedang, dan gizi baik. Sementara asupan karbohidratnya tidak berbeda secara signifikan.

Rerata pengukuran IMT, LILA, persen lemak tubuh, kekuatan genggam tangan, dan kadar $\mathrm{Hb}$ juga cenderung menurun seiring penurunan status gizi berdasarkan PG-SGA, meskipun secara statistik tidak signifikan. Perbandingan rerata asupan makan dan indeks status gizi tersebut dapat dilihat pada Tabel $\mathbf{3}$.

\section{Perbandingan rerata asupan dan status gizi pada kelompok kualitas hidup kurang dan baik}

Secara statistik, ada perbedaan yang signifikan pada asupan lemak dan skor PG-SGA antara pasien dengan kualitas hidup yang kurang dan baik. Secara keseluruhan, pada pasien yang kualitas hidupnya tergolong kurang, asupannya lebih rendah. Begitu pula dengan status gizi, hasil pengukuran IMT, LILA, persen lemak tubuh, kekuatan genggam tangan, dan kadar $\mathrm{Hb}$ juga lebih rendah pada pasien yang kualitas hidupnya kurang meskipun secara statistik tidak signifikan (Tabel 4). Skor PG-SGA lebih tinggi pada pasien dengan

Tabel 3. Perbedaan rerata asupan makan dan indeks status gizi pada kelompok status gizi kurang dan baik berdasarkan PG-SGA

\begin{tabular}{lcccc}
\hline \multirow{2}{*}{ Asupan dan indeks status gizi } & \multicolumn{2}{c}{ Status gizi berdasarkan PG-SGA } & \multirow{2}{*}{ p } \\
\cline { 2 - 4 } & PG-SGA A & PG-SGA B & PG-SGA C & \\
\hline Energi (kkal) & $1.331,4 \pm 381,5$ & $1.216,7 \pm 448,4$ & $863,6 \pm 476,3$ & $0,013^{*}$ \\
Protein (g) & $42,5 \pm 15,5$ & $39,4 \pm 18,7$ & $26,2 \pm 18,4$ & $0,043^{*}$ \\
Lemak (g) & $38,5 \pm 16,2$ & $31,0 \pm 19,0$ & $21,4 \pm 13,2$ & $0,016^{*}$ \\
Karbohidrat (g) & $203,8 \pm 65,8$ & $197,1 \pm 74,0$ & $141,2 \pm 83,9$ & 0,070 \\
IMT $^{2}\left(\mathrm{~kg} / \mathrm{m}^{2}\right)$ & $25,1 \pm 4,2$ & $24,6 \pm 5,2$ & $23,4 \pm 4,1$ & 0,568 \\
LILA $^{3}(\mathrm{~cm})$ & $28,7 \pm 3,7$ & $26,8 \pm 7,7$ & $27,6 \pm 4,9$ & 0,327 \\
Persen lemak tubuh (\%) & $33,5 \pm 6,5$ & $32,3 \pm 8,9$ & $29,1 \pm 12,5$ & 0,351 \\
Kekuatan genggam tangan (kg) & $16,6 \pm 8,7$ & $16,1 \pm 6,9$ & $15,6 \pm 4,1$ & 0,924 \\
Hemoglobin (mg/dl) & $12,5 \pm 0,9$ & $12,1 \pm 1,5$ & $12,4 \pm 1,1$ & 0,517 \\
\hline
\end{tabular}

${ }^{1} \mathrm{PG}-\mathrm{SGA}=$ Patient Generated-Subjective Global Assessment ${ }^{2} \mathrm{IMT}=$ Indeks Massa Tubuh;

${ }^{3}$ LILA=Lingkar Lengan Atas; *Signifikan $(\mathrm{p}<0,05)$ dengan uji One-way Annova

Tabel 4. Perbandingan rerata asupan dan status gizi pada kelompok kualitas hidup kurang dan baik

\begin{tabular}{lccc}
\hline \multirow{2}{*}{ Asupan dan status gizi } & \multicolumn{2}{c}{ Kualitas hidup } & \multirow{2}{*}{ p } \\
\cline { 2 - 3 } & Kurang & Baik & $0,105^{1}$ \\
\hline Energi (kkal) & $1189,7 \pm 467,5$ & $1326,7 \pm 369,7$ & $0,100^{1}$ \\
Protein (g) & $37,5 \pm 18,6$ & $43,1 \pm 15,2$ & $0,035^{1 *}$ \\
Lemak (g) & $31,0 \pm 16,9$ & $38,8 \pm 17,8$ & $0,419^{1}$ \\
Karbohidrat (g) & $192,3 \pm 79,8$ & $200,1 \pm 60,8$ & $0,261^{2}$ \\
IMT (kg/m $\left.{ }^{2}\right)$ & $24,3 \pm 4,5$ & $25,4 \pm 4,4$ & $0,778^{1}$ \\
LILA (cm) & $27,9 \pm 5,0$ & $28,0 \pm 5,9$ & $0,589^{1}$ \\
Persen lemak tubuh (\%) & $31,3 \pm 9,6$ & $34,4 \pm 5,1$ & $0,072^{2}$ \\
Genggam tangan $(\mathrm{kg})$ & $15,0 \pm 5,9$ & $18,1 \pm 9,4$ & $0,520^{2}$ \\
Hemoglobin (mg/dl) & $12,3 \pm 1,3$ & $12,5 \pm 1,0$ & \\
\hline
\end{tabular}

${ }^{1}$ Mann-Whitney U-test; ${ }^{2}$ Independent sample t-test; *Signifikan $(\mathrm{p}<0,05)$ 
Tabel 5. Hubungan status gizi dengan kualitas hidup

\begin{tabular}{|c|c|c|c|c|c|c|c|}
\hline \multirow{3}{*}{$\begin{array}{l}\text { Status } \\
\text { gizi }\end{array}$} & \multicolumn{4}{|c|}{ Kualitas hidup } & \multirow{3}{*}{ Total } & \multirow{3}{*}{$\mathbf{p}$} & \multirow{3}{*}{$\begin{array}{c}\text { RP } \\
\text { (CI } \\
95 \%)\end{array}$} \\
\hline & \multicolumn{2}{|c|}{ Buruk } & \multicolumn{2}{|c|}{ Baik } & & & \\
\hline & $\mathbf{n}$ & $\%$ & n & $\%$ & & & \\
\hline Malnutri & 25 & 71,4 & 10 & 28,6 & 35 & & 3,2 \\
\hline Baik & 22 & 44,0 & 28 & 56,0 & 50 & 0,01 & $(1,3-8,0)$ \\
\hline
\end{tabular}

kualitas hidup yang kurang, hal ini menunjukkan tingkat malnutrisi yang lebih berat berhubungan dengan semakin rendahnya kualitas hidup.

\section{Hubungan status gizi berdasarkan PG-SGA dengan kualitas hidup}

Secara statistik, terdapat hubungan yang signifikan antara status gizi dengan kualitas hidup. Nilai rasio prevalensi menunjukkan pasien yang tergolong malnutrisi memiliki risiko kualitas hidup yang kurang 3,2 kali lebih besar dibandingkan pasien dengan status gizi baik (Tabel 5).

\section{BAHASAN}

\section{Hubungan asupan makan terhadap status gizi}

Secara umum, asupan makan pasien kanker payudara dalam penelitian ini sebagian besar masih belum memenuhi kebutuhan. Sebagian besar responden memiliki asupan energi kurang $(54,1 \%)$, asupan protein kurang $(68,2 \%)$, asupan lemak kurang $(52,9 \%)$, dan sebanyak $47,1 \%$ responden memiliki asupan karbohidrat yang kurang. Setelah diuji secara statistik, terdapat perbedaan yang signifikan pada rerata asupan energi, protein, dan lemak antara pasien dengan status gizi baik, malnutrisi sedang, dan malnutrisi berat berdasarkan PG-SGA. Meskipun pada asupan karbohidrat tidak menunjukkan perbedaan yang signifikan secara statistik, tetapi terlihat rerata asupan yang terus menurun seiring penurunan status gizi. Hal ini menunjukkan adanya hubungan antara asupan makan dengan status gizi.

Asupan makan dapat dipengaruhi oleh beberapa faktor seperti nafsu makan, kemampuan menelan, dan penyerapan dalam tubuh (22). Pada kasus kanker, terjadi perubahan metabolisme karbohidrat, protein, dan lemak di dalam tubuh atau hipermetabolisme. Hipermetabolisme ini terjadi karena adanya sel kanker yang menyebabkan peningkatan kebutuhan glukosa sebagai sumber energi yang juga dapat mengakibatkan protein turn-over serta peningkatan lipolisis (23). Pemberian terapi radiasi atau kimia juga dapat mempengaruhi asupan makan. Terapi radiasi memberikan efek samping seperti penurunan nafsu makan, mual, muntah, stomatitis, tenggorokan kering, dan sulit menelan. Adanya efek samping yang terjadi pada saluran pencernaan tersebut mengakibatkan penurunan asupan makanan dan berdampak pada menurunnya status gizi (24).

Penilaian status gizi menggunakan kuesioner PGSGA menunjukkan bahwa 58,8\% responden tergolong status gizi baik (PG-SGA A); 31,8\% tergolong malnutrisi sedang (PG-SGA B); dan 9,4\% tergolong malnutrisi berat (PG-SGA C). PG-SGA merupakan pengembangan dari asesmen gizi menggunakan metode SGA khusus untuk pasien kanker. Metode ini menjadi rekomendasi American Dietetic Association karena menggali pertanyaan tentang adanya gejala terkait zat gizi, penurunan berat badan dalam jangka pendek, perubahan asupan makan serta pemeriksaan fisik seperti hilangnya lemak subkutan, massa otot, edema, dan ascites (25). Penelitian lain di Indonesia untuk menilai status gizi dengan kuesioner PG-SGA menunjukkan bahwa sebesar $41,4 \%$ responden tergolong malnutrisi sedang dan berat (26). Penelitian di Asia menunjukkan 29\% pasien tergolong PG-SGA A, 48\% pasien tergolong PG-SGA B, dan $23 \%$ pasien tergolong PG-SGA C (17). Sementara itu, penelitian di Australia menunjukkan $65 \%$ pasien memiliki status gizi baik; $28,3 \%$ pasien mengalami malnutrisi sedang; dan 6,7\% pasien mengalami malnutrisi berat (9).

Berdasarkan IMT, LILA, persen lemak tubuh, dan kekuatan genggam tangan, sebagian besar pasien kanker payudara memiliki status gizi baik hingga obesitas. Obesitas memang meningkatkan risiko kanker, terutama kanker kolorektal, payudara, ginjal, pankreas, endometrium, kandung empedu, dan esofagus (26). Namun demikian, hasil penelitian ini menunjukkan penurunan rerata IMT, LILA, persen lemak tubuh, kekuatan genggam tangan, dan kadar $\mathrm{Hb}$ pada pasien dengan status gizi yang tergolong PG-SGA A, B, dan C. Semakin berat kondisi malnutrisi (PG-SGA C), semakin rendah hasil pengukuran indeks antropometri dan $\mathrm{Hb}$.

Lebih lanjut, penelitian sebelumnya yang menghubungkan asupan dengan status gizi pada pasien 
kanker payudara dan kanker serviks yang dirawat inap juga menunjukkan hasil yang serupa. Asupan energi dan protein yang kurang ditemukan pada masing-masing $31,6 \%$ dan $54 \%$ pasien. Sebanyak $43,4 \%$ pasien tersebut tergolong ke dalam status gizi baik berdasarkan PG-SGA sedangkan $46,1 \%$ dan $10,5 \%$ pasien tergolong ke dalam malnutrisi dan malnutrisi berat. Setelah diuji secara statistik, diketahui adanya hubungan yang signifikan antara status gizi awal masuk rumah sakit terhadap asupan energi dan protein selama perawatan. Pasien dengan status gizi kurang, berisiko 1,1 kali memiliki asupan energi yang kurang dan 1,2 kali memiliki asupan protein yang kurang (27).

\section{Hubungan status gizi terhadap kualitas hidup}

Hasil penelitian menunjukkan bahwa secara statistik terdapat perbedaan yang signifikan pada rerata asupan lemak antara pasien dengan kualitas hidup kurang dan baik. Meskipun rerata asupan energi, protein, dan karbohidrat secara statistik tidak signifikan, tetapi terlihat bahwa asupan pasien lebih rendah pada responden dengan kualitas hidup kurang. Selain itu, rerata IMT, LILA, persen lemak tubuh, kekuatan genggam tangan, dan kadar $\mathrm{Hb}$ juga lebih rendah pada responden dengan kualitas hidup kurang, meskipun secara statistik tidak berbeda signifikan. Dengan demikian, dapat disimpulkan bahwa pasien yang memiliki asupan makan rendah dan status gizi kurang, kualitas hidupnya tergolong kurang.

Terdapat hubungan yang signifikan antara status gizi berdasarkan PG-SGA dengan kualitas hidup $(p=0,012)$. Pasien dengan status gizi kurang berdasarkan PG-SGA memiliki risiko kualitas hidup yang kurang 3,2 kali lebih besar dibandingkan pasien yang tergolong status gizi baik. Sejalan dengan penelitian lain yang menunjukkan bahwa pasien malnutrisi berisiko 3,76 kali lebih besar untuk memiliki kualitas hidup yang kurang (28). Penelitian sebelumnya telah mengkonfirmasi bahwa dengan kuesioner PG-SGA dan EORTC QLQ-C30, terdapat hubungan antara status gizi terhadap kualitas hidup ( $<<0,001)(9)$.

Kualitas hidup merupakan kepuasan dalam berbagai aspek kehidupan (29). Kualitas hidup pasien kanker payudara meliputi aspek fisik seperti perubahan nafsu makan, perubahan menstruasi, tidur, nyeri, dan kelelahan; aspek psikologis seperti kegunaan, kenyamanan, kecemasan atau depresi, dan kesedihan; aspek sosial yang terdiri dari hubungan pribadi, keluarga, lingkungan di rumah atau lingkungan kerja, dan beban keuangan; serta aspek spiritual terkait kepercayaan, harapan, dan tujuan hidup (13). Penurunan status gizi memiliki keterkaitan terhadap penurunan fungsi fisik, peningkatan gejala klinis, kehilangan tenaga serta penurunan sistem imun dan kondisi kesehatan secara umum yang akhirnya menurunkan kualitas hidup (30).

\section{SIMPULAN}

Asupan makan mempengaruhi status gizi dan kualitas hidup pada pasien kanker payudara yang menjalani radioterapi. Semakin rendah asupan pasien, status gizi cenderung semakin turun dan kualitas hidup tergolong buruk.

\section{Pernyataan konflik kepentingan}

Penulis menyatakan tidak ada konflik kepentingan dengan pihak-pihak yang terkait dalam penelitian ini.

\section{RUJUKAN}

1. Mardiana L. Kanker pada wanita. Jakarta: Niaga Swadaya; 2007.

2. WHO. World cancer report. [series online] 2003 [cited 2016 Nov 4]. Available from: URL: http://www.iarc.fr/ en/publications/pdfs-online/wcr/2003/

3. WHO. Globocan 2012 : Estimated cancer incidence, mortality and prevalence worldwide in 2012. [series online] 2012 [cited 2016 Nov 4]. Available from: URL: Available at: http://globocan.iarc.fr/Default.aspx

4. InfoDATIN. Situasi penyakit kanker. Jakarta: Kementerian Kesehatan Republik Indonesia; 2013.

5. Haryanti S. Faktor-faktor yang berhubungan dengan status gizi penderita kanker payudara wanita (studi kasus pada penderita kanker payudara wanita pasca rawat inap di Rumah Sakit Dr. Kariadi Semarang Tahun 2005) [Skripsi]. Semarang: Universitas Negeri Semarang; 2006.

6. Grant M, Kravits K. Symptoms and their impact on nutrition. Semin Oncol Nurs 2000;16(2):113-21.

7. De Jong W, Sjamsuhidajat R. Buku ajar ilmu bedah edisi revisi. Jakarta: EGC; 2004.

8. Gazali F. Kanker nasofaring: kenali, hindari, dan obati. Jakarta: FKUI; 2009. 
9. Isenring E, Bauer J, Capra S. The score patient-generated subjective global assessment (PG-SGA) and its association with quality of life in ambulatory patients receiving radiotherapy. Eur J Clin Nutr 2003;57(2):305-9.

10. Pressoir M, Desné S, Berchery D, Rossignol G, Poiree B, Bachmann P, et al. Prevalence, risk factor and clinical implication of malnutrition in French Comprehensive Cancer Centres. Br J Cancer 2010;102(6):966-71.

11. Hediningrum H. Faktor-faktor yang mempengaruhi status gizi pasien kanker payudara yang menjalani terapi di Instalasi Kanker Terpadu Tulip RSUP Dr. Sardjito Yogyakarta [Skripsi]. Yogyakarta: Universitas Gadjah Mada; 2008.

12. Prevost V, Joubert C, Heutte N, Babin E. Assessment of nutritional status and quality of life in patients treated for head and neck cancer. Eur Ann Otorhinolaryngol Head Neck Dis 2014;131(2):113-20.

13. Djuminten. Uji reabilitas instrumen kualitas hidup pada penderita kanker payudara di RSUP Dr. Sardjito Yogyakarta [Tesis]. Yogyakarta: Universitas Gadjah Mada; 2010.

14. Almatsier S. Penuntun diet. Jakarta: PT Gramedia Pustaka Utama; 2010.

15. Gibson RS. Principle of nutritional assessment, 2nd edition. New York: Oxford University Press; 2005.

16. Gallagher D, Heymsfield SB, Heo M, Jebb SA, Murgatroyd PR, Sakamoto Y. Healthy percentages body fat ranges: an approach for developing guideline based on body mass index. Am J Clin Nutr 2000;72(3):694-701.

17. Wang AY, Sea MM, Ho ZS, Lui SF, Li PK, Woo J. Evaluation of handgrip strength as a nutritional marker and prognostic indicator in peritoneal dialysis patients. Am J Clin Nutr 2005;81(1):79-86.

18. Kim HS, Lee JY, Lim SH, Cho J, Kim SJ, Kim K, et al. Patient-generated subjective global assessment as a prognosis tool in patients with multiple myeloma. Nutrition 2017;36:67-71.

19. Suwendar S, Fudhol A, Andayani TM, Sastramihardja HS. Analisis outcome humanistik pada pasien kanker serviks rawat inap selama menjalani kemoterapi di Rumah Sakit Umum Pusat Dr. Hasan Sadikin Bandung dengan menggunakan kuesioner EORTC QLQ-C30 versi 3. Prosiding SnaPP:Kesehatan 2015;1(1):169-174.
20. Janssen S, Glanzmann C, Lang S, Verlaan S, Streller T, Studer G, et al. Hypofractionated radiotherapy for breast cancer acceleration of the START A treatment regime: intermediate tolerance and efficacy. Radiat Oncol 2014;9:165.

21. Zeman FJ, Ney DM. Application of clinical nutrition. New Jersey: Prentice Hall; 1988.

22. Wilkes MG. Gizi pada kanker dan infeksi HIV. (Alih bahasa: Hartono A). Jakarta: EGC; 2000.

23. American Institute for Cancer Research. Heal, well, a cancer nutrition guide: healthy eating and activity for living. [series online] 2013 [cited 2016 Nov 4]. Available from: URL: http://www.aicr.org/assets/docs/pdf/education/ heal-well-guide.pdf

24. Ramos Chaves M, Boléo-Tomé C, Monteiro-Grillo I, Camilo M, Ravasco P. The diversity of nutritional status in cancer : new insight. Oncologist 2010;15(5):523-30.

25. Bauer J, Capra S, Ferquson M. Use of the scored PatientGenerated Subjective Global Assessment (PG-SGA) as a nutrition assessment tool in patients with cancer. Eur J Clin Nutr 2002;56(8):779-85.

26. Sudomo U. Experience in using score PG-SGA tool for screening and assessing nutritional in hospital patient. Jurnal Ilmiah Kesehatan RSPAD Gatot Soebroto 2001;1(2):8-11.

27. Susetyowati, Yenita, Johan K. Status gizi awal berdasarkan patient generated subjective global assessment (PG-SGA) berhubungan dengan asupan zat gizi dan perubahan berat badan pada penderita kanker rawat inap di RSUP DR Mohammad Hoesin Palembang. Jurnal Gizi Klinik Indonesia 2010;7(2):80-4.

28. Susetyowati, Pramantara IDP, Istutiningrum D. Association of malnutrition with quality of life, mortality and readmission post hospitalization in patients with noncommunicable disease. Pak J Nutr 2016;15(8):771-6.

29. Prastiwi TB. Kualitas hidup penderita kanker. Developmental and Clinical Psychology 2012;1(1):21-7.

30. Kurniawan A, Lugito NPH. Nutritional status and quality of life in breast cancer patients in Karawaci General Hospital. Indonesian Journal of Cancer 2016;10(1):1-4. 